CLINICAL STUDY

\title{
Ultrasensitive serum thyroglobulin measurement is useful for the follow-up of patients treated with total thyroidectomy without radioactive iodine ablation
}

\author{
C Nascimento ${ }^{1}$, I Borget ${ }^{2}$, F Troalen ${ }^{3}$, A Al Ghuzlan ${ }^{3}$, D Deandreis ${ }^{1}$, D Hartl ${ }^{4}$, J Lumbroso ${ }^{1}$, C N Chougnet $^{1}$, \\ E Baudin $^{1}$, M Schlumberger $^{1}$ and S Leboulleux ${ }^{1}$ \\ Departments of ${ }^{1}$ Nuclear Medicine and Endocrine Oncology, ${ }^{2}$ Biostatistic and Epidemiology, ${ }^{3}$ Medical Biology and Pathology and \\ ${ }^{4}$ Surgery, Institut Gustave Roussy, Univ. Paris Sud, 114 Rue Edouard Vaillant, 94805 Villejuif Cedex, France \\ (Correspondence should be addressed to C Nascimento; Email: camilalnascimento@gmail.com)
}

\begin{abstract}
Context: Thyroglobulin ( $\mathrm{Tg}$ ) measurement is a major tool for the follow-up of differentiated thyroid cancer (DTC) patients; however, in patients who do not undergo radioactive iodine (RAI) ablation, normal ultrasensitive $\mathrm{Tg}$ levels measured under levothyroxine treatment $\left(\mathrm{usTg} / \mathrm{L}-\mathrm{T}_{4}\right)$ are not well defined.

Objective and design: This single-center retrospective study assessed usTg/L- $\mathrm{T}_{4}$ level in 86 consecutive patients treated with total thyroidectomy without RAI ablation for low-risk DTC $(n=77)$ or for tumors of uncertain malignant potential (TUMP) $(n=9)$.

Results: DTCs were classified as pT1, pT2, and pT3 in 75, 1, and 1 case respectively and pNO, pN1, and $\mathrm{pNx}$ in 40, 6, and 31 respectively. Following surgery, ten patients had Tg antibodies ( $\mathrm{TgAb}$ ). Among those without $\mathrm{TgAb}$, the first $\mathrm{usTg} / \mathrm{L}-\mathrm{T}_{4}$ determination obtained at a mean time of 9 months after surgery was $\leq 0.1 \mathrm{ng} / \mathrm{ml}$ in $62 \%$ of cases, $\leq 0.3 \mathrm{ng} / \mathrm{ml}$ in $82 \%$ of cases, $\leq 1 \mathrm{ng} / \mathrm{ml}$ in $91 \%$, and $\leq 2 \mathrm{ng} / \mathrm{ml} \mathrm{in} 96 \%$ of cases. After a median follow-up of 2.5 years (range: 0.6-7.2 years), one patient had persistent disease with an usTg/L- $\mathrm{T}_{4}$ at $11 \mathrm{ng} / \mathrm{ml}$ and an abnormal neck ultrasonography (US) and two patients had usTg/L-T 4 level $>2 \mathrm{ng} / \mathrm{ml}$ ( 3.9 and $4.9 \mathrm{ng} / \mathrm{ml}$ ) with a normal neck US. Within the first 2 years following total thyroidectomy without RAI ablation, usTg/L-T $\mathrm{T}_{4}$ level is $\leq 2 \mathrm{ng} / \mathrm{ml}$ in $96 \%$ of the cases.

Conclusion: After total thyroidectomy, sensitive serum $\mathrm{Tg} / \mathrm{L}-\mathrm{T}_{4}$ level is $\leq 2 \mathrm{ng} / \mathrm{ml}$ in most patients and can be used for patient follow-up.
\end{abstract}

European Journal of Endocrinology 169 689-693

\section{Introduction}

The incidence of differentiated thyroid cancer (DTC) in the last 20 years is predominantly due to the increased detection of small papillary thyroid cancers, classified as low-risk DTC $(1,2,3)$. The recurrence rate of these low-risk DTCs is $<5 \%$ and the benefits of radioactive iodine (RAI) ablation on the survival rate or on the risk of recurrence have not been demonstrated $(4,5,6)$. RAI ablation for low-risk DTC patients is therefore recommended in only selected cases, preferably using a minimal RAI activity and recombinant human thyroid-stimulating hormone (rhTSH) stimulation $(7,8,9,10,11)$.

A major argument for RAI administration after surgery is to facilitate follow-up by destroying remnants of normal thyroid tissue, turning serum thyroglobulin $(\mathrm{Tg})$ into a very specific tumor marker. However, it has been shown that the serum $\mathrm{Tg}$ level measured on levothyroxine $\left(\mathrm{L}-\mathrm{T}_{4}\right)$ treatment remains a valuable tool for follow-up even in the absence of RAI ablation, with a
$\mathrm{Tg}$ level below $1 \mathrm{ng} / \mathrm{ml}$ in $93-95 \%$ of cases $(12,13)$. Among 290 patients treated with total thyroidectomy, in the absence of RAI ablation and with a median follow-up of 5 years, 95\% of them had a Tg level of $<1 \mathrm{ng} / \mathrm{ml}$, measured with a Tg assay with functional sensitivity of $1 \mathrm{ng} / \mathrm{ml}$, and the only patient who relapsed had an increased serum Tg level (13).

Ultrasensitive $\mathrm{Tg}$ (usTg) assays with functional sensitivity of $0.1 \mathrm{ng} / \mathrm{ml}$ are now available (14). Following treatment with total thyroidectomy and RAI ablation, usTg measured under $\mathrm{L}^{-\mathrm{T}_{4}}$ treatment (usTg/L- $\mathrm{T}_{4}$ ) is able to discriminate patients at risk of recurrence, with different thresholds defined, depending on the study, at 0.15 or $0.27 \mathrm{ng} / \mathrm{ml}(15,16)$.

Few data on the usefulness of usTg measurement following total thyroidectomy and in the absence of RAI are available. Using an usTg assay with a functional sensitivity of $0.2 \mathrm{ng} / \mathrm{ml}$, Durante et al. (13) showed that $60 \%$ of patients had an undetectable $(<0.2 \mathrm{ng} / \mathrm{ml}) \mathrm{Tg}$ level within 12 months after surgery and $79 \%$ within 5 years after surgery. 
The aim of this single-center retrospective study was to assess usTg/L- $\mathrm{T}_{4}$ after total thyroidectomy without RAI ablation for low-risk DTC or tumors of uncertain malignant potential (TUMP).

\section{Subjects and methods}

\section{Patients}

Approval from our institutional review board was obtained for the study. Files of consecutive patients seen in the thyroid clinic between January 2006 and December 2010 with a pathological diagnosis of DTC, TUMP, or both, confirmed by our pathologist (A A G) and who underwent total thyroidectomy with or without neck lymph node dissection and did not receive RAI for ablation were reviewed. Another inclusion criterion was at least one serum Tg measurement on $\mathrm{L}^{-} \mathrm{T}_{4}$ treatment performed at our institution 1-36 months after initial surgery.

Follow-up, usually once annually following surgery, was based on physical examination and usTg/L- $\mathrm{T}_{4}$. Neck ultrasonography (US) was performed at 9 months after surgery and then at the discretion of physicians.

\section{Tg measurement}

Serum Tg measurement was performed using the chemiluminescent immunoenzymatic «sandwich» assay, Access Thyroglobulin, automated on UniCel DxI 800 instruments (Beckman Coulter, Villepinte, France) with an analytical sensitivity of $0.1 \mathrm{ng} / \mathrm{ml}$. The Tg level was considered as not accurately measured in the presence of $\mathrm{Tg}$ antibodies $(\mathrm{TgAb})$ that were quantitatively measured with Access Thyroglobulin Antibody II assay (Beckman Coulter) in routine at each serum Tg determination, with a reference range of $0-4 \mathrm{IU} / \mathrm{ml}$.

Serum TSH was measured using the Access HYPERsensitive human TSH (hTSH) assay, a third-generation two-site immunoenzymatic (sandwich) assay automated on Access II Immunoassay System instrument (Beckman Coulter, Fullerton, CA, USA), with a reference range of $0.34-5.60 \mathrm{mIU} / \mathrm{l}$.

\section{Neck US}

Neck US was performed with a high-resolution ultrasound system (Aplio ultrasound machine; Toshiba Medical, Puteaux, France) equipped with a high-energy $14 \mathrm{MHz}$ linear probe (PZT; Toshiba), allowing to work in fundamental B-mode (lateral resolution: $0.17 \mathrm{~mm}$; axial resolution: $0.11 \mathrm{~mm}$ ) and in power Doppler mode (rate of 12 frames/s, limit detection of $5 \mathrm{~cm} / \mathrm{s}$ with a pulse repetition frequency (PRF) of $17 \mathrm{KHz}$ ). US examination included both central and lateral neck compartments. Suspicion of a malignant lymph node was based on the following criteria: hyperechoic punctuations, cystic appearance, peripheral hypervascularization, round-shape node without hyperechoic hilum, and a short axis $>7 \mathrm{~mm}$ (17). Neck US was considered abnormal when lymph node metastasis was confirmed with a fine-needle aspiration biopsy (FNAB) for cytology and $\mathrm{Tg}$ measurement in the aspirate fluid. Neck US was considered a false positive when FNAB did not show any evidence of malignancy and/or when subsequent neck US was normal. In the other cases, neck US was considered suspicious for malignancy.

\section{Statistical analysis}

Quantitative data were expressed in means and s.D. and qualitative data were expressed in percentages.

\section{Results}

\section{Patients}

The clinical characteristics of the 86 patients (66 females, mean age 50 years, range $15-86$ years) who form the basis of this retrospective study are

Table 1 Characteristics of patients.

\begin{tabular}{|c|c|}
\hline & $n=86$ patients \\
\hline \multicolumn{2}{|l|}{ Sex } \\
\hline Male & $20(23 \%)$ \\
\hline Female & $66(87 \%)$ \\
\hline Mean age \pm S.D. (range) & $50 \pm 13$ (15-86 years) \\
\hline \multicolumn{2}{|l|}{ Histology } \\
\hline Papillary thyroid cancer & $67(78 \%)$ \\
\hline Follicular thyroid cancer & $4(5 \%)$ \\
\hline TUMP alone & $9(10 \%)$ \\
\hline Papillary+TUMP & $6(7 \%)$ \\
\hline \multicolumn{2}{|l|}{ Variant of thyroid cancer } \\
\hline Tall cell & $1(1 \%)$ \\
\hline Oncocytic & $3(3 \%)$ \\
\hline \multicolumn{2}{|l|}{ Classification (without TUMP) } \\
\hline $\mathrm{pT} 1 \mathrm{~N} 0 / \mathrm{pT} 1 \mathrm{~N} 1 / \mathrm{pT} 1 \mathrm{Nx}$ & $40 / 5 / 30$ \\
\hline pT2N0/pT2N1/pT2Nx & $0 / 1 / 0$ \\
\hline pT3N0/pT3N1/pT3Nx & $0 / 0 / 1$ \\
\hline Bilateral tumor & $13(15 \%)$ \\
\hline Multifocal tumor & $21(24 \%)$ \\
\hline \multicolumn{2}{|l|}{ Tumor size (mm) } \\
\hline$\leq 20$ & $84(98 \%)$ \\
\hline $20-40$ & $1(1 \%)$ \\
\hline$>40$ & $1(1 \%)$ \\
\hline \multicolumn{2}{|l|}{ Central node dissection } \\
\hline None & $37(43 \%)$ \\
\hline Central only & $3(3 \%)$ \\
\hline $\begin{array}{l}\text { Central + ipsilateral (compartments III } \\
\text { and IV) }\end{array}$ & $43(50 \%)$ \\
\hline Central + bilateral & $3(3 \%)$ \\
\hline \multicolumn{2}{|l|}{ Lymph node metastases (without TUMP) } \\
\hline Presence in neck compartment: & 6 \\
\hline Central only & 2 \\
\hline Central and lateral & 1 \\
\hline Lateral only & 3 \\
\hline Absent & 40 \\
\hline Unknown (no neck dissection) & 31 \\
\hline
\end{tabular}

TUMP, tumors of uncertain malignant potential. 
reported in Table 1 . Total thyroidectomy was performed in our center in 74 cases $(86 \%)$. Lymph node dissection was performed in 49 patients $(57 \%)$ : three patients had bilateral central neck dissection, 43 had bilateral central and ipsilateral lateral neck dissection (compartments III and IV), and three had bilateral central and bilateral lateral neck dissection. Tumors were DTC in 77 cases $(90 \%)$ and TUMP in nine cases (10\%). According to the 2010 pTNM scoring system for DTC, tumors were classified as pT1 in 75 cases $(97 \%)$, pT2 in one case (1\%), and pT3 in one case (1\%). Lymph node metastases were present in six (8\%) cases (pN1), absent in $40(52 \%)$ cases (pNO), and lymph node status was unknown in 31 $(40 \%)$ cases $(\mathrm{pNx})$. Five of the six patients with lymph node metastases had only one metastatic lymph node without extension beyond the lymph node capsule, and the remaining patient had eight metastatic lymph nodes with an extension beyond the capsule of one invaded lymph node. pTNM is detailed in Table 1. RAI ablation was not performed in the seven patients with intermediate risk DTC (7), because of a single lymph node metastasis in five cases, a wish of pregnancy in a 40-year-old woman who had pT1N1b DTC and poor clinical condition in an 86-year-old woman who had a pT3Nx DTC.

\section{Serum usTg levels}

Postoperative usTg/L- $\mathrm{T}_{4}$ level was measured in the 76 patients without anti-TgAb at a mean time of 9 months after surgery (range: $1-34 \mathrm{~m}$ ): it was $\leq 0.1 \mathrm{ng} / \mathrm{ml}$ in 47 cases $(62 \%), \leq 0.3$ in 62 cases $(82 \%), \leq 1 \mathrm{ng} / \mathrm{ml}$ in 69 cases $(91 \%)$, and $\leq 2 \mathrm{ng} / \mathrm{ml}$ in 73 cases $(96 \%)$; the concomitant median TSH level was $0.48 \mathrm{mIU} / \mathrm{l}$ (mean: 1.56; range: $0.01-15.34 \mathrm{mIU} / \mathrm{l})$. The percentage of patients with a TSH level $>2 \mathrm{mIU} / \mathrm{l}$ increased with the $\mathrm{Tg}$ level, but the association between these categories was not statistically significant (Table 2). In the remaining three patients, usTg/L- $\mathrm{T}_{4}$ was $3.9,4.9$, and $11 \mathrm{ng} / \mathrm{ml}$ with evidence of disease only present in the

Table 2 Level of postoperative usTg/L- $T_{4}$ in the absence of $\mathrm{TgAb}$ and TSH level.

\begin{tabular}{lccc}
\hline & $\begin{array}{c}\text { Number of } \\
\text { patients } \\
n(\%)\end{array}$ & $\begin{array}{c}\text { Number of } \\
\text { patients with } \\
\text { TSH level } \\
>\mathbf{2} \text { mUI/l } n(\%)\end{array}$ & $\begin{array}{c}\text { TSH level (mlU/I) } \\
\text { Range (median) }\end{array}$ \\
\hline $\begin{array}{c}\text { usTg/L-T } \mathbf{4}(\mathrm{ng} / \mathrm{ml}) \\
<0.1\end{array}$ & $33(44)$ & $4(12)$ & $2.22-7.9$ \\
$0.1-0.3$ & $29(38)$ & $8(28)$ & $2.01-14.76$ \\
$0.4-1$ & $7(9)$ & $3(43)$ & $4.6-15.34$ \\
$1.1-2$ & $4(5)$ & $2(50)$ & $2.66-3.31$ \\
$>2$ & $3(4)$ & 0 & - \\
Tg group (ng/ml) & & & \\
$\leq 0.1$ & $47(62)$ & $7(15)$ & $2.06-14.76(0.44)$ \\
$\leq 0.3$ & $62(82)$ & $12(19)$ & $2.01-14.76(0.45)$ \\
$\leq 1.0$ & $69(91)$ & $15(22)$ & $2.01-15.3(0.47)$ \\
$\leq 2.0$ & $73(96)$ & $17(23)$ & $2.01-15.3(0.48)$ \\
\hline
\end{tabular}

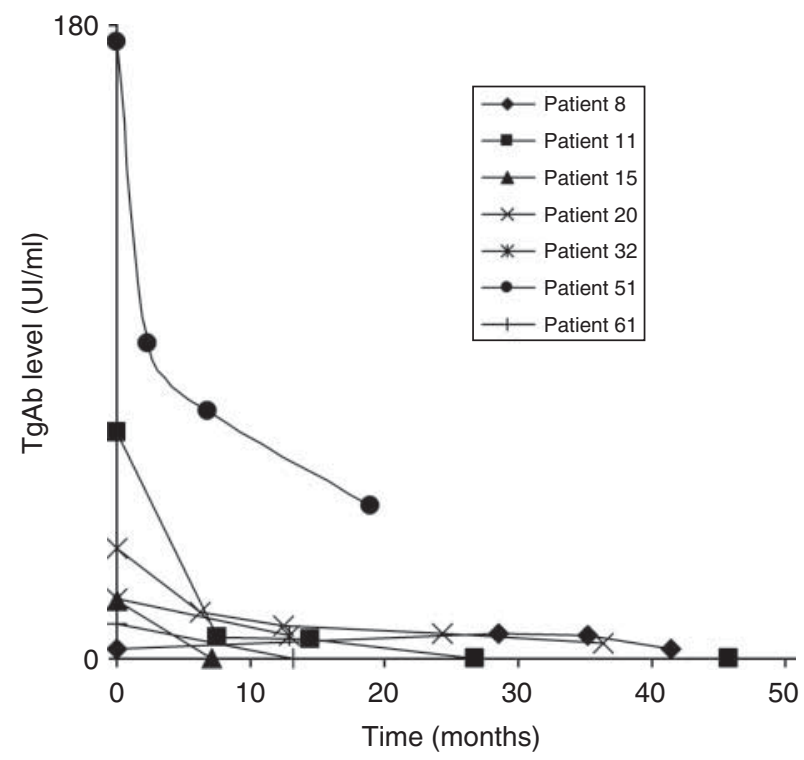

Figure 1 Follow-up of patients with detectable serum TgAB.

latter patient (Table 2). Among the ten patients with detectable postoperative $\mathrm{TgAb}$, the median postoperative $\mathrm{TgAb}$ level was $24.1 \mathrm{IU} / \mathrm{ml}$ (mean $=67.5$, range: 2.6-288.7 IU/ml) and was above the upper limit of the normal range in nine patients.

\section{Neck US and follow-up}

During a median follow-up of 2.5 years (range: 0.6-7.2 years), neck US was performed in 72 patients $(81 \%)$. It was normal in 67 cases including the two patients with a usTg level of 3.9 and $4.9 \mathrm{ng} / \mathrm{ml}$. It was abnormal in the patient with a usTg/L- $\mathrm{T}_{4}$ level of $11 \mathrm{ng} / \mathrm{ml}$, who had a thyroid cancer recurrence. It was suspicious for malignancy in four cases, but thyroid cancer recurrence was not confirmed in any of these cases with subsequent normal neck US in two cases, lymphoma in one case, and normal benign ectopic thyroid tissue histologically proven in the remaining case.

Among the ten patients with detectable serum $\mathrm{TgAb}$, seven were followed up and TgAb became undetectable in three patients, decreased by more than $60 \%$ in three, and remained stable in one patient (Fig. 1).

The patient with persistent disease was a 20-yearold woman with a pT1Nx papillary carcinoma. Her usTg/L-T 4 level measured 7 months after surgery was $11 \mathrm{ng} / \mathrm{ml}$, as described earlier, with metastatic neck lymph nodes in both lateral compartments at neck US. She underwent central and bilateral neck dissection, with six metastatic lymph nodes being removed in both lateral compartments. Following surgery, this patient was considered cured with an usTg level $\leq 1 \mathrm{ng} / \mathrm{ml}$ and a normal neck US. 


\section{Discussion}

Properly selected low-risk DTC patients can be treated with surgery only, without RAI ablation, without decreasing long-term disease-free survival $(12,18)$. The follow-up of DTC patients is based on neck US and serum $\mathrm{Tg}$ measurement, with an undetectable serum $\mathrm{Tg}$ being a criterion of cure. In the absence of RAI ablation, a detectable serum $\mathrm{Tg}$ level may be related to persistent disease or normal thyroid remnants (19, 20, 21, 22).

Our study confirms that serum usTg/L- $\mathrm{T}_{4}$ in the absence of $\mathrm{TgAb}$ is a valid tool for the follow-up of patients who did not receive RAI ablation, even in the absence of suppressed TSH levels. In our study, a high usTg/L- $\mathrm{T}_{4}$ level was observed in the only case of persistent disease that was confirmed by an abnormal neck US and surgery. Moreover, most patients do have a level lower than $2 \mathrm{ng} / \mathrm{ml}(96 \%)$ within the first year following total thyroidectomy. Following RAI ablation, usTg/L- $\mathrm{T}_{4}$ levels are lower than 0.15 or $0.27 \mathrm{ng} / \mathrm{ml}$ $(15,16)$ in $84 \%$ of the patients. We similarly found usTg $/ \mathrm{L}-\mathrm{T}_{4}$ level below $0.3 \mathrm{ng} / \mathrm{ml}$ in $82 \%$ of the patients during the first year of follow-up, which was the threshold $(0.27 \mathrm{ng} / \mathrm{ml})$ with the best sensitivity and specificity for defining complete ablation in our previous study (15). In the rare patients with a higher serum $\mathrm{Tg}$ level, the evolution - increasing or decreasing - of serum $\mathrm{Tg} / \mathrm{L}-\mathrm{T}_{4}$ during subsequent follow-up is a major tool to interpret $\mathrm{Tg} / \mathrm{L}-\mathrm{T}_{4}$, even in the absence of RAI ablation $(13,23,24,25)$.

Interestingly, we observed that $\mathrm{TgAb}$ spontaneously decreased in most cases, as observed after RAI ablation (26). Although this needs to be confirmed on a larger series of patients, this suggests that the presence of $\mathrm{TgAb}$ may not be an argument for RAI administration.

Our study is, however, limited by its retrospective design, a short follow-up of less than 10 years (27), fewer patients, and the absence of neck US performed in all patients, which may detect small lymph node metastases in the absence of elevated serum $\operatorname{Tg}(27,28)$. Our results are also dependent on the quality of the surgery performed and can only be applied in patients who underwent total thyroidectomy with a small remnant, and this is the case in our center (29). It may not apply in patients who underwent less than total thyroidectomy.

In conclusion, for DTC patients well operated by total thyroidectomy and with small thyroid remnants in the absence of RAI ablation, serum usTg measurement is a useful tool for the follow-up. The usTg/L- $\mathrm{T}_{4}$ is $\leq 2 \mathrm{ng} / \mathrm{ml}$ in most patients.

\section{Declaration of interest}

The authors declare that there is no conflict of interest that could be perceived as prejudicing the impartiality of the research reported.

\section{Funding}

C Nascimento received a grant from DUERTECC/EURONCO (Diplôme Universitaire Européen de Recherche Translationnelle Et Clinique en Cancérologie).

\section{Acknowledgements}

The authors are indebted to Catherine Martin for secretarial assistance.

\section{References}

1 Davies L \& Welch HG. Increasing incidence of thyroid cancer in the United States, 1973-2002. Journal of the American Medical Association 2006295 2164-2167. (doi:10.1001/jama.295.18.2164)

2 Sassolas G, Hafdi-Nejjari Z, Remontet L, Bossard N, Belot A, Berger-Dutrieux N, Decaussin-Petrucci M, Bournaud C, Peix JL, Orgiazzi J et al. Thyroid cancer: is the incidence rise abating? European Journal of Endocrinology 2009160 71-79. (doi:10.1530/ EJE-08-0624)

3 Hughes DT, Haymart MR, Miller BS, Gauger PG \& Doherty GM. The most commonly occurring papillary thyroid cancer in the United States is now a microcarcinoma in a patient older than 45 years. Thyroid 201121 231-236. (doi:10.1089/thy.2010.0137)

4 Tuttle RM, Tala H, Shah J, Leboeuf R, Ghossein R, Gonen M, Brokhin M, Omry G, Fagin JA \& Shaha A. Estimating risk of recurrence in differentiated thyroid cancer after total thyroidectomy and radioactive iodine remnant ablation: using response to therapy variables to modify the initial risk estimates predicted by the new American Thyroid Association staging system. Thyroid 201020 1341-1349. (doi:10.1089/thy.2010.0178)

5 Sacks W, Fung CH, Chang JT, Waxman A \& Braunstein GD. The effectiveness of radioactive iodine for treatment of low-risk thyroid cancer: a systematic analysis of the peer-reviewed literature from 1966 to April 2008. Thyroid 201011 1235-1245. (doi:10.1089/ thy.2009.0455)

6 Schvartz C. Bonnetain F, Dabakuyo S, Gauthier M, Cueff A, Fieffé S, Pochart JM, Cochet I, Crevisy E, Dalac A et al. Impact on overall survival of radioactive iodine in low-risk differentiated thyroid cancer patients. Journal of Clinical Endocrinology and Metabolism 201297 1526-1535. (doi:10.1210/jc.2011-2512)

7 Cooper DS, Doherty GM, Haugen BR, Kloos RT, Lee SL, Mandel SJ, Mazzaferri EL, McIver B, Pacini F, Schlumberger M et al. Revised American Thyroid Association management guidelines for patients with thyroid nodules and differentiated thyroid cancer. Thyroid 200919 1167-1214. (doi:10.1089/thy.2009.0110)

8 Jonklaas J, Cooper DS, Ain KB, Bigos T, Brierley JD, Haugen BR, Ladenson PW, Magner J, Ross DS, Skarulis MC et al. Radioiodine therapy in patients with stage I differentiated thyroid cancer. Thyroid 201020 1423-1424. (doi:10.1089/thy.2010.0308)

9 Schlumberger M, Borget I, Nascimento C, Brassard M \& Leboulleux S. Treatment and follow-up of low-risk patients with thyroid cancer. Nature Reviews. Endocrinology 20117 625-628. (doi:10.1038/nrendo.2011.133)

10 Mallick U, Harmer C, Yap B, Wadsley J, Clarke S, Moss L, Nicol A, Clark PM, Farnell K, McCready R et al. Ablation with low-dose radioiodine and thyrotropin alfa in thyroid cancer. New England Journal of Medicine $2012 \mathbf{1 8}$ 1674-1685. (doi:10.1056/ NEJMoa1109589)

11 Schlumberger M, Catargi B, Borget I, Deandreis D, Zerdoud S, Bridji B, Bardet S, Leenhardt L, Bastie D, Schvartz C et al. Strategies of radioiodine ablation in patients with low-risk thyroid cancer. New England Journal of Medicine 201218 1663-1673. (doi:10.1056/NEJMoa1108586)

12 Durante C, Attard M, Torlontano M, Ronga G, Monzani F Costante G, Ferdeghini M, Tumino S, Meringolo D, Bruno R et al. Identification and optimal postsurgical follow-up of patients 
with very low-risk papillary thyroid microcarcinomas. Journal of Clinical Endocrinology and Metabolism 201095 4882-4888. (doi:10.1210/jc.2010-0762)

13 Durante C, Montesano T, Attard M, Torlontano M, Monzani F, Costante G, Meringolo D, Ferdeghini M, Tumino S, Lamartina L et al. Long-term surveillance of papillary thyroid cancer patients who do not undergo postoperative radioiodine remnant ablation: is there a role for serum thyroglobulin measurement? Journal of Clinical Endocrinology and Metabolism 201297 2748-2753. (doi:10.1210/jc.2012-1123)

14 Spencer C, Fatemi S, Singer P, Nicoloff J \& Lopresti J. Serum basal thyroglobulin measured by a second-generation assay correlates with the recombinant human thyrotropin-stimulated thyroglobulin response in patients treated for differentiated thyroid cancer. Thyroid 201020 587-595. (doi:10.1089/thy. 2009.0338)

15 Brassard M, Borget I, Edet-Sanson A, Giraudet AL, Mundler O, Toubeau M, Bonichon F, Borson-Chazot F, Leenhardt L, Schvartz C et al. Long-term follow-up of patients with papillary and follicular thyroid cancer: a prospective study on 715 patients. Journal of Clinical Endocrinology and Metabolism 201196 1352-1359. (doi:10.1210/jc.2010-2708)

16 Malandrino P, Latina A, Marescalco S, Spadaro A, Regalbuto C, Fulco AR, Scollo C, Vigneri R \& Pellegriti G. Risk-adapted management of differentiated thyroid cancer assessed by a sensitive measurement of basal serum thyroglobulin. Journal of Clinical Endocrinology and Metabolism 201196 1703-1709. (doi:10.1210/jc.2010-2695)

17 Leboulleux S, Girard E, Rose M, Travagli JP, Sabbah N, Caillou B, Hartl DM, Lassau N, Baudin E \& Schlumberger M. Ultrasound criteria of malignancy for cervical lymph nodes in patients followed up for differentiated thyroid cancer. Journal of Clinical Endocrinology and Metabolism 200792 3590-3594. (doi:10.1210/ jc.2007-0444)

18 Vaisman F, Shaha A, Fish S \& Tuttle RM. Initial therapy with either thyroid lobectomy or total thyroidectomy without radioactive iodine remnant ablation is associated with very low rates of structural disease recurrence in properly selected patients with differentiated thyroid cancer. Clinical Endocrinology 201175 112-119. (doi:10.1111/j.1365-2265.2011.04002.x)

19 Grunwald F, Menzel C, Fimmers R, Zamora PO \& Biersack HJ. Prognostic value of thyroglobulin after thyroidectomy before ablative radioiodine therapy in thyroid cancer. Journal of Nuclear Medicine 199637 1962-1964.

20 Ronga G, Filesi M, Ventroni G, Vestri AR \& Signore A. Value of the first serum thyroglobulin level after total thyroidectomy for the diagnosis of metastases from differentiated thyroid carcinoma. European Journal of Nuclear Medicine 199926 1448-1452. (doi:10.1007/s002590050477)
21 Oyen WJ, Verhagen C, Saris E, van den Broek WJ, Pieters GF \& Corsten FH. Follow-up regimen of differentiated thyroid carcinoma in thyroidectomized patients after thyroid hormone withdrawal. Journal of Nuclear Medicine 200041 643-646.

22 Toubeau M, Touzery C, Arveux P, Chaplain G, Vaillant G, Berriolo A, Riedinger JM, Boichot C, Cochet A \& Brunotte F. Predictive value for disease progression of serum thyroglobulin levels measured in the postoperative period and after (131)I ablation therapy in patients with differentiated thyroid cancer. Journal of Nuclear Medicine 200445 988-994.

23 Van Wyngaarden K \& McDougall R. Is serum thyroglobulin a useful marker for thyroid cancer in patients who have not had ablation of residual thyroid tissue? Thyroid 19973 343-346. (doi:10.1089/thy.1997.7.343)

24 Miyauchi A, Kudo T, Miya A, Kobayashi K, Ito Y, Takamura Y, Higashiyama T, Fukushima M, Kihara M, Inoue H et al. Prognostic impact of serum thyroglobulin doubling-time under TSH suppression in patients with papillary thyroid carcinoma who underwent total thyroidectomy. Thyroid 201121 707-716. (doi:10.1089/ thy.2010.0355)

25 Pacini F, Sabra MM \& Tuttle RM. Clinical relevance of thyroglobulin doubling time in the management of patients with differentiated thyroid cancer. Thyroid 2011 7 691-692. (doi:10.1089/thy.2011.2107.ed1)

26 Chiovato L, Latrofa F, Braverman LE, Pacini F, Capezzone M, Masserini L, Grasso L \& Pinchera A. Disappearance of humoral thyroid autoimmunity after complete removal of thyroid antigens. Annals of Internal Medicine 2003139 346-351. (doi:10.7326/ 0003-4819-139-5_Part_1-200309020-00010)

27 Ross DS, Litofsky D, Ain KB, Bigos T, Brierley JD, Cooper DS, Haugen BR, Jonklaas J, Ladenson PW, Magner J et al. Recurrence after treatment of micropapillary thyroid cancer. Thyroid 200919 1043-1048. (doi:10.1089/thy.2008.0407)

28 Torlontano M, Crocetti U, Augello G, D’Aloiso L, Bonfitto N, Varraso A, Dicembrino F, Modoni S, Frusciante V, Di Giorgio A et al. Comparative evaluation of recombinant human thyrotropinstimulated thyroglobulin levels, ${ }^{131}$ I whole-body scintigraphy, and neck ultrasonography in the follow-up of patients with papillary thyroid microcarcinoma who have not undergone radioiodine therapy. Journal of Clinical Endocrinology and Metabolism 200691 60-63. (doi:10.1210/jc.2005-1185)

29 Cailleux AF, Baudin E, Travagli JP, Ricard M \& Schlumberger M. Diagnostic iodine-131 scanning useful after total thyroid ablation for differentiated thyroid cancer? Journal of Clinical Endocrinology and Metabolism 200085 175-178. (doi:10.1210/jc.85.1.175)

Received 7 May 2013

Revised version received 18 July 2013

Accepted 12 August 2013 